\title{
Hong Kong and Singapore: Two approaches to the provision of pensions in Asia \\ Received: 7th September, 2001
}

\section{Mukul Asher}

is Professor of Public Policy at the National University of Singapore. He was educated in India and the United States and has a $\mathrm{PhD}$ in economics from Washington State University. He is currently on leave visiting the Asian Development Bank Institute in Tokyo, Japan.

\section{David Newman}

is Associate Professor and Deputy Director of the Public Policy Programme at the National University of Singapore. He has a PhD from the University of Rochester in political science and a juris doctorate from the Franklin Pierce Law Center.

\begin{abstract}
This paper analyses the differing practices of the two affluent Asian financial centres of Hong Kong and Singapore with respect to providing income security to their rapidly ageing populations. Compared to Singapore's 50 -year-old CPF, which is centrally managed, non-transparent and non-accountable, Hong Kong's MPF scheme, begun in 2000, incorporates nearly all the best international pension fund management and governance practices. Moreover, while members of the MPF earn market rate of returns and enjoy considerable choice, CPF members earn interest that bears no resemblance to returns from investing their assets, and its members enjoy very limited choice. However, both the MPF and CPF members do not enjoy protection against longevity and inflation risks, and do not address the needs of the lifetime poor.
\end{abstract}

Keywords: Asian financial centres; Hong Kong's Mandatory Provident Fund (MPF); Singapore's Central Provident Fund (CPF); managing pension reserves; pension fund governance; financing old age; life insurance; mutual funds; social assistance; notional defined benefit

David Newman Public Policy Programme, National University of Singapore, Shaw Foundation Building, AS7 6th Floor, Singapore 117570.

Tel: 65-874-3324; Fax: 65-778-1020 e-mail: mppdn@nus.edu.sg

Mukul Asher Visiting Scholar, Asian Development Bank Institute, Kasumigaseki Building, 8th Floor, 3-2-5 Kasumigseki, Chiyoda-ku, Tokyo, 100-6008, Japan.

Tel: 81-3-3593-5500; e-mail: mppasher@nus.edu.sg

\section{Introduction}

Hong Kong and Singapore are the two major financial centres in Southeast Asia and, as Table 1 suggests, are similar in many ways. Both are former British colonies that have adopted the common law tradition and Western notions of trusts, fiduciary duty and prudent investor. Both have relatively high standards of living, high levels of education, few, if any, individuals involved in agricultural production, low birth rates, considerable inward migration from outside, very high levels of urbanisation, high life expectancy, moderate income inequality, and limited requirements to respond to domestic political pressures.

Despite these similarities, the two city-states have adopted very different policies with respect to providing income security to an increasingly aged population. ${ }^{1}$ Singapore relies on a mandatory savings system (called the Central Provident Fund or CPF) managed centrally by a government 
Table 1: Comparison of Hong Kong and Singapore

\begin{tabular}{lcc}
\hline & Hong Kong & Singapore \\
\hline Population (1999) $^{*}$ & 6.8 million & 3.9 million \\
Land area (1000 sq km) & 1.1 & 0.6 \\
Per capita GNP (1998 US\$) & 23,660 & 30,170 \\
Total fertility rate (births per woman) (1998) & 1.1 & 1.5 \\
Percent of population over age 65 (2000) & 10.5 & 7.2 \\
Life expectacy (women/men) & $82 / 76$ & $80 / 75$ \\
Urban population (1999) & 95.6 & 100 \\
Urban growth rate (1994-1999) & 1.1 & 1.6 \\
Gini coefficient & 0.37 & 0.39 \\
Percent of population economically active & $49 / 76$ & $51 / 78$ \\
(women/men) & & 198 \\
Stock market capitalisation (1999 (US\$) & 609 & 355 \\
Listed companies & 695 & 858 \\
insurance (1999 US\$) & & 858 \\
\hline
\end{tabular}

Notes: Singapore population figures include permanent and non-permanent residents staying over one year. Hong Kong figure includes permanent and non-permanent residents.

Sources: Except as otherwise noted: <http://www.adb.org/Documents/Books/Key_Indicators/2000/tables1-40. pdf $>$. Stock market capitalisation, listed company data from Standard and Poors (2000). Annual expenditures on life insurance from Swiss Re (2000).

statutory board to provide retirement protection. $^{2}$ The CPF was established in 1955, before independence, and falls under the purview of the Ministry of Manpower. Effective in April 2001, Singaporean wage earners can also voluntarily contribute to a tax advantaged supplementary retirement scheme. Hong Kong's mandatory provident scheme (MPF) was introduced in 1995 and became operational in December 2000. ${ }^{3}$ The MPF is regulated by a statutory body, but its administrative and investment functions are undertaken in a decentralised manner. This paper examines the structure and performance of the two very different approaches. In addition, since insurance and mutual funds are playing an increasing role in the private provision of pensions in both cities, these are also examined.

\section{Singapore}

\section{Central Provident Fund}

The CPF is governed by a board whose members are appointed by the Minister of Manpower, and comprises representatives of government, employer, employees, and professionals. While the $\mathrm{CPF}$ and its board have responsibility for routine administrative matters, they do not have policymaking and investment responsibilities. As of March 2001, 2.9m Singaporeans were members of the CPF and members' balances totalled S\$90bn. The balances are in effect invested primarily by the Government of Singapore Investment Corporation, whose legal status is that of a private limited company — removing it from parliamentary or public scrutiny. Nominally, on the CPF Board's balance sheet, the investments is in effect only in non-marketable government securities, whose interest is the same as whatever the CPF Board pays its members.

Under the CPF scheme, employers contribute 16 per cent and employees, up to the age of 55 , contribute 20 per cent of wages net of employers' share. ${ }^{4}$ There is a wage ceiling of $\mathbf{\$} \$ 6,000$ per month. Contributions are credited into three accounts maintained on behalf of employees: ordinary account, special account and medisave account. The percentages contributed to each account 
vary with age but up to age 55 , as one ages the amount going to the ordinary account declines from 72.2 per cent to 61.1 per cent of contributions and the amount going to the medisave account increases from 16.67 per cent to 22.2 per cent of contributions. The smallest share is credited to the special account for retirement. Benefits vest immediately and are portable.

CPF savings are not just for retirement. Members are allowed to tap their balances for a variety of purposes including: housing, medical needs, and education in approved institutions. While contribution rates appear to be high, the typical member's contributions in any given month are deposited by the employer and then immediately withdrawn by the employee to make a mortgage housing payment. In effect the CPF scheme substitutes for the absence of a housing mortgage market. ${ }^{5}$ Average CPF balances in 2000 are roughly S $\$ 31,000$ (US $\$ 16,000)$ - hardly adequate to form the foundation of a retirement plan.

A member is permitted to invest his ordinary and special account balances in deposits, government bonds, statutory board bonds, government guaranteed bonds, deferred annuities, endowment insurance policies, and subject to further regulation, unit trusts, investment linked insurance products, shares, corporate bonds, and gold (see discussion of CPFIS below).

\section{Supplementary Retirement Scheme}

Effective from April 2001, Singapore citizens and permanent residents could save 15 per cent of their total labour compensation, subject to a ceiling, in a voluntary tax advantaged account. The accounts can only be opened at one of four locally owned and controlled banks. Expatriate employees are also eligible and they can contribute at a rate of 35 per cent in recognition of the fact that they are not a part of the CPF scheme. Employers are not permitted to contribute to the SRS, but the self-employed may join.

The contributions and investment income (except dividend income) can be accumulated in a tax-advantaged manner until the statutory retirement age at the time of first contribution (currently age 62). At the time of statutory withdrawals, 50 per cent of the amount is taxed at then prevailing marginal income tax rate — introducing additional uncertainty. The tax benefit thus varies positively with the marginal income tax rate. Premature withdrawals not only attract full tax, but also a 5 per cent penalty. As only about a third of the labour force currently is liable for individual income tax, the SRS scheme is of relevance only to the top third of the labour force. Foreigners must maintain any SRS account for at least ten years even if they leave Singapore earlier.

With the exception of property, real estate, and some forms of insurance, SRS contributions may be invested in a variety of assets. Withdrawals, however, must be made in cash but can be staggered over time to minimise tax or avoid adverse market conditions.

In addition to the small proportion of the labour force that is likely to find SRS of relevance, there are also other reasons for its limited impact. First, for many Singaporeans, the high CPF rates mean that the remainder of their income is committed to basic necessities.

Secondly, since Singapore employs a source based income taxation system, income earned abroad but not remitted to Singapore is not subject to income tax. Hence the benefits derived from the SRS, particularly for foreigners, are limited. Thirdly, the transaction costs of the scheme are likely to be high given limited competition, absence of 
regulation on fees and charges, and small size of the unit-trust industry. In addition, taxation at the withdrawal stage will reduce returns. Fourth, the income tax payable at the time of withdrawal is on both original investment and on capital gains. Since Singapore has no capital gains, under some circumstances, such as when a person joins the SRS at a young age and has a low marginal rate of tax, and when net returns on SRS investments are high, an individual may actually get a lower rate of after-tax return under the SRS as compared to not enjoying the tax benefit. Usually, it is the taxation of capital gains that make the SRS type schemes tax advantaged.

In Singapore, capital gains, with the exception of some property transactions, are exempt from the income tax. The investment income from the investment of SRS funds is taxable at the life insurance company level, thus discriminating against the use of life insurance products by the SRS participants. Fifth, the ten-year minimum period for which an expatriate must maintain balances in the SRS account could act as a hindrance for short-term expatriates. Sixth, expatriates must take into account the exchange rate risks as their liabilities are likely to be in non-Singapore currency; and the risk that income tax rates (and relevant transaction costs) are not known. The exchange risk is non-trivial given the volatility in exchange rates, external openness of Singapore's economy, and the vulnerability of the Southeast Asian region to globalisation forces, particularly the emergence of China as a major economic factor.

\section{Hong Kong's Mandatory Provident Fund}

Hong Kong's MPF is designed to cover workers aged 18 to 65 . Mandatory contributions are 10 per cent of an employee's relevant income with the employer and employee each paying 5 per cent. ${ }^{6}$ Self-employed persons are required to contribute 5 per cent of their income on either a monthly or yearly basis. ${ }^{7}$ Employees who are engaged in the catering or construction industries on a day-to-day basis for a fixed period of less than 60 days are defined as casual employees and are covered. Contributions for casual employees are made in accordance with a published scale amount. Employees earning less than HK\$4,000 (US\$540) per month are not required to contribute but employers are not exempt from their 5 per cent levy. There is a wage ceiling of HK $\$ 20,000$ on mandatory contributions but both employees and employers can opt to make extra voluntary contributions. Benefits vest immediately and are portable. By March 2001, 82 per cent of employers, 92 per cent of employees, and 90 per cent of self-employed persons were enrolled in MPF schemes (MPFSA 2001). By May 2001, compliance figures were 85 per cent, 93 per cent, and 95 per cent, respectively — very high for so early. ${ }^{8}$

Regulations provide that employers are required regularly to inform employees of the details of provident fund contributions paid on their behalf to the scheme trustee. A trustee is required to provide a notice to participants at the time of acceptance, a membership certificate, a document containing a general description of the scheme including the fees and charges payable under the scheme, particulars of the constituent funds of the scheme, and an annual benefit statement within three months after the end of the scheme's financial year. The statement is required to show the opening balance of accrued benefits, the amount of any contributions made to the scheme during the year, and 
the closing balance of accrued benefits at the scheme's yearend.

Mandatory provident fund accounts in Hong Kong can either be set up as a master-trust, governing multiple companies, an industry scheme governing a sector such as catering or construction, or a company scheme (limited to a single employer or affiliated group of companies). Master trust schemes are estimated to cost $90-100$ basis points of assets. A company scheme, of which there are only two so far and which only makes sense for large companies, 'has higher initial set up costs but lower on-going costs'.,10 Fees for master trust agreements geared toward small and medium enterprises are in the range of 1.625 per cent of assets while competition among other segments of the market have reduced fees from 1.8 to 1.5 per cent of net assets. ${ }^{11}$

There is the requirement that 30 per cent of the funds be invested in Hong Kong dollar-denominated securities. This keeps a certain amount of money captive in Hong Kong, regardless of government policies or the local investment climate. Scheme participants have invested 45.6 per cent of all funds in balanced funds, 22.5 per cent in guaranteed funds, 15.2 per cent in equity funds, 14 per cent in capital preservation funds, and the balance in money market and bond funds. ${ }^{9}$

Contributions and accrued earnings must remain in the MPF until the member reaches age 65 , has died, retired early and attained age 60 , or retires between age 60 and 65 . In addition, if a member is departing permanently from Hong Kong or is totally incapacitated, he or she may remove the accumulated benefits. Members can withdraw their accumulated benefits at age 65 in a single lump sum. There is no requirement to annuitise the benefit and a more developed annuity market would enhance old age planning. Hence, the MPF scheme does not address longevity or inflation risk and does not provide for survivors' benefits. ${ }^{12}$ Thus, the life-time poor are likely to be under provided for.

By March 2001, MPF net assets totalled HK $\$ 15,694 \mathrm{~m}$ (MPFSA 2001) and total assets were estimated to reach HK\$1trn (US $\$ 130$ bn) by 2016 .

\section{Returns}

\section{Singapore}

CPF has not provided members with high enough real returns to capture the power of compound interest (see Figure 1). There are two pools of funds invested by the CPF board. The first, which is by far the largest, are the balances left with the CPF board that are not in the insurance pool. These balances amounted to $\$ \$ 90.3 \mathrm{bn}$ at the end of 2000. On the CPF balance sheet, 100 per cent is shown as invested in non-marketable government securities. The interest on these securities is exactly identical to the interest rate paid by the CPF board on members' balances. This rate is a weighted average of the one year fixed deposit rate ( 80 per cent) paid by four domestic banks and the savings rate $(20$ per cent) calculated quarterly. Thus, short-term interest is being paid on long-term CPF savings. This shows the administered nature of the interest rate on CPF balances.

While CPF members know their account balances, they do not know the basis or performance of investment decisions and there is no correspondence between investment returns and member returns. This, in conjunction with 100 per cent of the funds being invested (nominally in Singapore's case) in government securities has transformed the nominal DC-FF (defined contribution - 


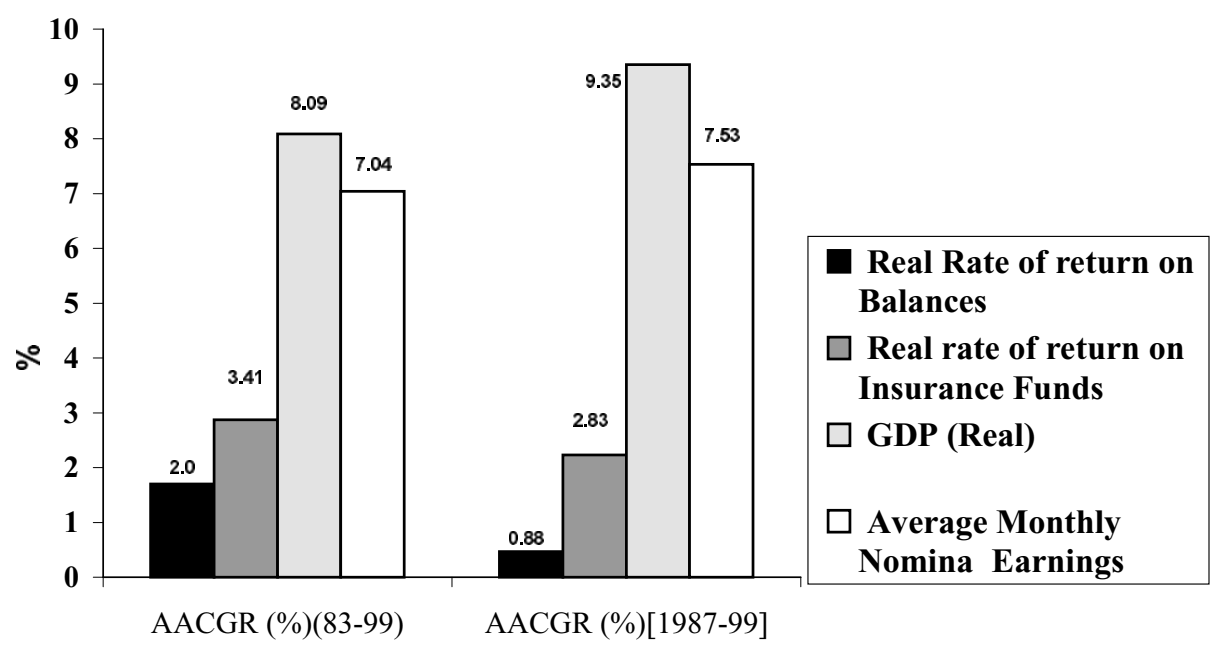

Figure 1: Singapore's CPF - Average Annual Compound Growth Rate (AACGR)

fully funded) nature of the CPF scheme into a notional defined benefit (NDB) scheme financed on a pay-as-you-go basis. ${ }^{13}$ Singapore's unusual position of having a persistent budget surplus and a high level of internal debt ( $\$ 134,370 \mathrm{~m}$ in 2000, 84.5 per cent of GDP) can be explained by the use of CPF balances for purchase of non-marketable government securities.

The second pool consists of insurance funds for health care, mortgage, and basic life insurance, which amounted to $\$ \$ 2.9 \mathrm{bn}$ at the end of 1999. These funds are contracted out to investment mangers, and their portfolio is published in the CPF Board's annual reports. For the 1983-1999 period, the annual real rate of return was 2 per cent for the first pool of funds, and 3.41 per cent for the insurance funds (Figure 1). If the 1987-1999 period is taken, the returns were even lower being 0.88 per cent and 2.83 per cent respectively.

In both periods, the returns were substantially lower than the rate of growth in GDP and of nominal earnings (Figure 1). This relationship is important because if the return on balances is lower than the growth of income and wages, then the replacement rate that can be obtained from the accumulated balances of the members is likely to be low. Another indication of the inadequate replacement rate in retirement is the ratio of the average balance per member to average monthly earnings. This ratio already low at 11.6 in 1987 has fallen further to 9.9 in 1999 even as life expectancy has risen. ${ }^{13}$

The third pool of funds for investment consists of pre-retirement withdrawals by members under the CPF Investment Scheme (CPFIS). Until 30th September, 2001, individuals could withdraw 100 per cent of the profits realised (less accrued interest which would have been payable by the CPF Board on all the amounts withdrawn under this scheme). This proportion will reduce to 50 per cent from 1st October, 2001 and from 30th September, 2002 will be zero per cent. This is designed to close a loophole under which potential profits on pre-retirement savings can be made from tax-advantaged savings but these do not contribute to the objective of mandatory accumulation of savings for retirement. As at 31st December, 2000, under the CPFIS scheme, $\$ \$ 18.741 \mathrm{bn}$ (US\$10.771bn) had been withdrawn by 
516,386 members (17.8 per cent of total members). The average investment per member thus was $\mathbf{S} \$ 36,293$ (US $\$ 20,858$ ).

The latest figures available for the allocation of investments under the CPFIS scheme are until 31st March, 2001. Total investment as of that date was $\$$ \$20.192bn (US\$11.218bn). The allocation was as follows: stocks and loan stocks: $\mathbf{S} \$ 9,550 \mathrm{~m}$ (47.3 per cent); insurance policies: $\mathbf{S} \$ 9,063 \mathrm{~m}$ (44.9 per cent); unit trusts; $\mathrm{S} \$ 1,285 \mathrm{~m}$ (6.4 per cent); and other: $\mathrm{S} \$ 294 \mathrm{~m}$ (1.5 per cent). Between the third and fourth quarters of 2000, investment in insurance policies grew the most ( 7 per cent) followed by unit trusts $\left(3.6\right.$ per cent). ${ }^{14}$

Transaction costs for unit trusts are high with 5 to 7 per cent spread between the offer and bid (buy and sell) prices. Although there has been an effort made to address this issue, the low average investment and small size of the unit trusts market are constraints. In addition, there is an annual investment management fee of between 1-2 per cent of total investments of members. Therefore, investment performance under this scheme appears to be unsatisfactory. ${ }^{15}$ But additional data are needed from the CPF Board for a more detailed and robust research result.

The decumulation phase is important because during retirement it is essential to provide protection against inflation, longevity risks, and to ensure benefits to survivors. Since women have a lower exposure to labour force than men, and they earn on average less than men, but have longer life expectancy, protection against the above risk is particularly important for them.

At the time of retirement, a lump-sum payment, periodic withdrawals, an annuity, or a combination of the three are all options in a DC scheme to convert accumulated balances into a flow of income during retirement. ${ }^{16}$ The CPF permits its members to withdraw all accumulated balances over and above the required minimum sum at age 55 . As of July of 2001, the required minimum sum is $\$ 70,000$ of which $\$ 30,000$ must be in cash and $\$ 40,000$ can be pledged in property. The minimum sum will become $\$ 80,000$ in July 2003 with the amount equally divided between cash and property. Currently, there are no further plans to increase the minimum sum. Although a significant proportion of CPF members' have accumulated balances that fall below the minimum sum, if a member's balances are below the required minimum sum, they do not have to make it up from other sources. Children are, however, allowed to top up parents' CPF accounts.

The CPF Board permits three options for the cash component of the minimum sum: buy a life annuity from an approved insurance company, keep it with an approved bank, or leave it with the CPF Board. In 1999, fewer than 10 per cent of the 26,000 individuals who were covered under the Minimum Sum Scheme purchased annuities. Thus, the annuities option is not popular. Under all three options, the first payment is not available until age 62, seven years after the withdrawal age. The seven-year gap, while desirable from the point of view of overall public policy goals, nevertheless could create genuine hardships for some individuals.

The above arrangements effectively increase the politically sensitive withdrawal age for this component. However, the main weaknesses of the mandatory savings scheme centering on inadequate balances for many individuals, and the need for protection against inflation and longevity, and the provision of survivors' benefits are not addressed by the minimum sum scheme. 


\section{Hong Kong}

There is very little track record to go on with respect to the MPF. The plan became operational in December 2000 and employers had until 29th January, 2001 to enroll employees and until 10th February, 2001 to make their first contributions. The Mandatory Provident Fund Schemes Authority (MPFSA) reported in March 2001, that $\mathrm{HK} \$ 11.6 \mathrm{~b}$ (US\$1.5b) was invested under the scheme, including monies transferred from ORSO plans, in some 299 approved funds. The rate of return any particular member will achieve will determined by his fund selection and it is still too early to determine how well the average investor will do over time. However, for 2001, more than half of the 290 MPF investment funds recorded a negative return to 30 th April. ${ }^{18}$ In aggregate we know that as of March 2001, 46 per cent of the funds were invested in share and bond funds, 21 per cent in guaranteed funds (funds with a contracted rate of return (generally long term and sometimes investment linked), 15 per cent in equity funds, 15 per cent in Hong Kong deposit accounts, 2 per cent in money market funds and 1 per cent in bond funds. What is likely to improve returns in Hong Kong over time is increased competition over fees. By the first quarter 2001, Citibank, in cooperation with a variety of US mutual fund companies, introduced no-load fund offerings for MPF accounts with annual management fees as low as 50 basis points.

\section{Life Insurance in Hong Kong and Singapore}

Hong Kong's life insurance market is well established with Hong Kong residents spending more money on life insurance products per capita (US\$859) than any other country in the region with the exception of Japan. ${ }^{19}$ The Insurance Companies Ordinance Chapter 41 governs insurance and Hong Kong can adopt a 'light-handed' approach to regulation since it operates under a common law legal system that recognises fiduciary duties and a prudent person investor rule.

Specifically, for long-term insurance (life insurance), Hong Kong relies on a 'full-fledged actuary system' whereby every life insurer carrying business in or from Hong Kong must appoint an actuary to undertake annual actuarial investigation. Under the Insurance Companies (Actuaries' Standards) Regulation, effective January 2001, an appointed actuary has to comply with the Professional Standard 1 issued by the Actuarial Society of Hong Kong, which contains prudent person rules with respect to investments. In an annual report submitted to the Insurance Authority, s(he) 'must certify whether there is a prudent and satisfactory relationship between the nature and term of the assets and liabilities of a life insurer.'

Under this system, the Insurance Companies Ordinance does not have specific restrictions on investments, specific restrictions on self-ownership or concentration of ownerships with respect to investments, and specific restrictions on foreign assets ownerships for life insurers. The burden falls on the actuary.

Hong Kong has in recent years begun to introduce some consumer protection initiatives with respect to insurance. These include a Claims Complaint Bureau with the power to make financial awards, a cooling off period allowing a purchaser of life insurance to cancel the policy, and a variety of standard disclosure forms for both investment linked and non-unit 
trust sales which must be provided given to prospective purchasers of these products.

Singapore's 1999 life insurance expenditures per capita are just about on par with those of Hong Kong $(\text { US } \$ 858)^{19}$ with 1999 total life insurance policies being $3,554,887$ and premiums totalling $\mathrm{S} \$ 552 \mathrm{mn}(<\mathrm{https} / /$ secure.mas. gov.sg/dataroom/insurance1999/ ins_lifedata-c.html). The annuity business was much smaller comprising just 17,974 policies. The market is served by 62 direct insurers most of whom are foreign owned. ${ }^{20}$

Regulation of the insurance industry comes under the purview of the Insurance Department of the Financial Sector Supervision and Promotion section of the Monetary Authority of Singapore. 'The Insurance Department administers the Insurance Act, which governs the licensing of insurance companies, and monitors insurer's financial resources to meet their obligations to policyholders and claimants, and their compliance with prudential standards as stipulated in the Act'. ${ }^{20}$

In both Hong Kong and Singapore there is a penchant for whole life insurance policies with more than 50 per cent of the new long-term premiums in Hong Kong being written as individual life policies (<http://www.info. gov.hk/oci/>). In 2000, more than half of the annual new long-term insurance business (as measured by premium dollars) was in individual life policies. While the Insurance Commissioner provides no breakdown, it can be assumed that some of these policies were straight life insurance policies providing simply survivor benefits. Some policies had a cash value that could be converted to retirement savings. Less than 1 per cent of the premiums purchased group life and annuity or individual annuity policies. Just fewer than 10 per cent of all premiums were invested in retirement schemes and 35.5 per cent was invested in long term-linked schemes that are often but not for certain used for retirement.

In Singapore in 2000, 5,144 new annuity policies were written while at the same time 617,204 new life insurance policies were written. Overall, there are 22,864 annuity policies in force in Singapore and overall $4 \mathrm{~m}$ life policies. Again, the same concern exists that heavy marketing of life products may have resulted in an over-consumption of survivor benefits at the expense of an annuitised stream of income in one's later life.

\section{Mutual Funds in Hong Kong and Singapore}

In both Hong Kong and in Singapore, the governments are increasingly relying on private mutual fund companies to provide investment vehicles for private retirement schemes. The mutual fund industry in Hong Kong is very thick with more than 1,870 authorised mutual funds with more than US $\$ 311 \mathrm{bn}$ invested as of December 2000. ${ }^{21}$ This consists of both local and foreign funds. The Securities and Futures Commission regulates the industry.

In Singapore, the government has explicitly sought to make Singapore a hub of investing. While the international component is relatively large and active, with $\$$ \$246bn under management in 1999, the domestic component in mutual funds remains small. As of 1999, there were 25 unit trust managers managing a total of 187 Singapore-registered unit trusts with trust assets totalling $\mathrm{S} \$ 6.8 \mathrm{bn}$. Equity funds formed the bulk of the unit trusts. Net subscriptions of unit trusts for 1999 amounted to $\mathrm{S} \$ 1.5 \mathrm{bn}$, representing a more than three-fold growth over the 
previous year. Of the total 187 unit trusts, 64 were approved under the CPF investment scheme. Of the $\$ \$ 3.3 \mathrm{bn}$ of $\mathrm{CPF}$-approved unit trusts, $\mathrm{S} \$ 1.0 \mathrm{bn}$ or 31 per cent had been purchased using CPF monies, with the balance of $\mathrm{S} \$ 2.3 \mathrm{bn}$ purchased using cash (<https://secure. mas.gov.sg/surveys/FMSurvey/ fmsurvey1999fullindex.html >). This reflects a per capita holdings of slightly more than US\$1,300 in 1999.

Unfortunately in both, but more so in Singapore, the costs attached to servicing a relatively small market with a broad array of investment funds is expensive and fees for investing for long-term retirement through mutual fund companies are likely significantly to erode long-term returns.

Mutual fund fees in Hong Kong are generally comparable to those paid in Europe: an average annual management fee of 1.37 per cent and an overall expense ratio of 2.1 per cent. ${ }^{22}$ Hong Kong's Tracker Fund, the Hong Kong government's effort to offload shares acquired during the Asian financial crisis, has overall management fees of just 20 basis points - comparable to index funds in the USA.

Singapore's Monetary Authority (MAS) has been highlighting the costs of both investment linked insurance products and unit trusts in an effort to improve transparency and perhaps push overall cost down. At the end of 2000 , the MAS proposed barring unit trusts from charging for advertising to the funds and the closure of funds that failed to reach a minimum size. ${ }^{23}$ At least one fund reported an expense ratio of more than 5 per cent in the first quarter 2001 and at least 14 funds had expense ratios of more than 2.8 per cent. Several articles have appeared in the Singapore Business Times in recent months highlighting the high costs and low returns of domestic funds. ${ }^{24}$

\section{Conclusions}

The analysis in this paper suggests that there are similarities as well as differences in the arrangements for pensions for non-civil servants in the two city-states and financial centres of Hong Kong and Singapore.

Both are essentially nominally relying on a mandatory savings tier as the primary instruments for providing old-age security. Hong Kong's scheme, however, started in December 2000, while Singapore's scheme is nearly five decades old, set up when it was still a British colony.

Hong Kong's MPF is a focused mandatory savings scheme for retirement with no pre-retirement withdrawals permitted; while Singapore's scheme has multiple objectives with extensive pre-retirement withdrawals and correspondingly a contribution rate which is nearly four times that of Hong Kong.

Hong Kong's MPF has a rigorous and transparent regulatory framework, with decentralised investment management and administration. Thus, the weight given to fiduciary responsibilities of the fund trustees is comparable to international best practices. In Singapore, both investment and administration are centrally managed. While the CPF Board undertakes administrative functions with a high degree of efficiency and transparency, the investment function is performed by the government investment holding company whose policies and performance are legally non-transparent and non-accountable to the CPF members. The members receive an administered rate of interest that does not correspond to returns actually earned on the members' balances. The difference between the earned return and paid return is not disclosed.

Thus, in spite of having nominally the same mandatory savings pillar, in actual 
impact, Singapore's system resembles a notional defined benefit system financed on a pay-as-you-go basis. This is an irony as Singapore's policymakers have publicly inveighed against such as system. As greater experience is gained with Hong Kong's MPF system, an interesting experiment on the outcome of decentralised vs. centralised mandatory savings schemes will become available. Any lessons, however, would need to be drawn carefully, differentiating between returns to individual members and returns to the economy as a whole and the impact on the efficiency of the saving-investment process.

In both entities, accumulations under the mandatory savings pillar need not be mandatorily translated into an income stream, ie, an annuity. Strictly, neither entity is a pension scheme as opposed to a mandatory savings scheme. Thus, the extent to which their populations will be provided with inflation and longevity protection and survivors' benefits will depend on the insurance markets. This is because neither entity has a significant tax financed redistributive pillar. $^{25}$

The analysis further suggests caution in drawing inferences from the nominal nature of the pension systems, and underlines the importance of details of design and actual implementation of the schemes. The extent to which these two high income financial centres are able to improve currently inadequate social security provision for their citizens will be of much wider interest, particularly in the other high income countries with relatively small and homogeneous populations.

\section{References}

1 For convenience to Hong Kong is referred to as a city-state. Technically it is the Hong Kong Special Administrative Region of China and nominally it is supposed to enjoy 50 years of a high degree of autonomy following more than 150 years of British rule. Under the Basic Law, Hong Kong's mini-constitution, articles 107 and 108, Hong Kong is committed to keeping taxes low and expenditures in line with revenues.

2 The discussion in this paper is confined to non-civil servants. Hong Kong operates two statutory, non-contributory pension schemes for civil servants: the Old Pension Scheme (OPS), which is governed by the Pensions Ordinance (Cap. 89) (for those appointed before 1st July, 1987) and the New Pension Scheme (NPS) (Pension Benefits Ordinance (Cap. 99)), for those appointed on or after 1st July, 1987. The main differences between the OPS and the NPS are the retirement age, provision for early retirement, provision for deferred pension on resignation and the maximum commuted pension gratuity (ie, the percentage of pensions payable as a lump sum upon retirement). Both schemes provide for annual adjustments tied to changes in the consumer price index (<http://www.hku.hk/hkgcsb/ csreform/english/eannexa.htm $>$ ). Civil servants progressing onto permanent status in 2003 and beyond will be brought under a Civil Service Provident Scheme under the MPF. In Singapore, through two conversions in 1973 and 1987, most civil servants have been brought under the purview of the system for non-civil servants (Asher 2000). Currently, only the elite administrative service officials, high level security, defence personnel, and political office holders are eligible for non-contributory defined benefit pensions which are protected against longevity and inflation risks and are financed through the budget.

3 Prior to the introduction of the MPF and since 1993, Hong Kong regulated voluntary retirement schemes under the Occupational Retirement Schemes Ordinance (Cap. 426)(ORSO). About one third of the workforce was covered by a retirement scheme prior to 2000. After the implementation of MPF, 84 per cent of the workforce was covered (<http://www.mpfahk.org/eng/mpf/2_1.htm>). ORSO plans can continue to operate, can be used as a top-up or supplement to MPF, or can be wound down. Initial reports indicate that a higher than expected percentage of ORSO plans are being converted to MPF plans.

4 These rates are effective for most employees as of January 2001. The government reduced contributions during the Asian financial crisis and is now trying to restore the cuts to previous levels. The target contribution rate is 40 per cent - half from the employer and half from the employee. In addition, those above age 55 and those in pensionable government positions contribute at different rates.

5 The authors thank Thomas Snyder for clarifying some of our thoughts on these issues.

6 Relevant income includes wages, salaries, leave pay, fee, commission, bonus, gratuity, perquisite and allowances, but excludes housing (allowance or benefit) <http://www.mpfahk.org/eng/mpf/ 2_2.htm>.

7 Self-employed hawkers and domestic workers are 
exempt from the scheme.

8 PensionsAsia 2001 'Modest metrics, outsize impact', North Asia Pension Reform: A Closer Look, PensionsAsia, Hong Kong, pp. 25-28.

9 MPFSA (Mandatory Provident Fund Scheme Authority) (2001) 'Annual Report 2000-2001', Mandatory Provident Fund Schemes Authority, Hong Kong.

10 DiBiasio, Jame (2001b) 'The Trailblazer', Pensions Asia, Hong Kong, A FinanceAsia Publication, March.

11 DiBiasio, Jame (2001a) 'And They're Off', Pensions Asia, Hong Kong, A FinanceAsia Publication, March.

12 A shift in consumer preference for whole life to term insurance coupled with purchase through MPF would aid in the provision of survivors' benefits.

13 Asher, Mukul and Wasana, Karunarathne. (2001) 'Social Security Arrangements in Singapore: An Assessment', Discussion Paper No. 9, Institute of Economic Research, Hitotsubashi University, Japan.

14 Business Times (Singapore) 27th February, 2001.

15 Even guarantee funds in Singapore, offering a 2 per cent guaranteed return and a higher expected return based on a mix of bond and stock investments, are quickly hobbled by initial sales charges of 2.75 per cent, a management fee, and a performance fee (equal to 30 per cent of all gains above the guaranteed return), perform poorly relatively to plain deposit accounts (Business Times (Singapore) 18th July, 2001).

16 It is understood that annuities are like any other financial product, so cost of purchasing an annuity and therefore rate of return from an annuity purchase varies with the market structure and the features of the annuity product (individual vs. joint annuity, inflation indexing etc.). In Singapore expenses are estimated to be about 4 per cent of the premium (which in the case of an annuity equals the principal amount which is invested to give a stream of income), including a 1 per cent sales commission, plus a large management fee (see James and Vittas 1999). ${ }^{17}$

17 James, E. and Vittas, D. (1999) 'Annuities Markets in Comparative Perspective: Do Consumers Get Their Money's Worth?' Prepared for presentation at conference on New Ideas About Old Age Security, The World Bank, Washington, DC.

18 South China Morning Post, 1st June, 2001.

19 Swiss Re. 2000 'World Insurance in 1999: Soaring life insurance business', Sigma No 9/2000.

20 Organization for Economic Cooperation and Development (OECD) (1999) 'Insurance regulation and supervision in Asia', OECD, Paris.

21 Hong Kong Securities and Futures Commission (2001) Securities and Futures Commission Annual Report 2000-2001, <http://www.hksfc.org.hk/ eng/press_releases/html/index.html $>$

22 The management fee is the fee charged by a mutual fund company against the fund assets for managing the fund. The overall expense ratio is the total of both the management fee and administration expenses charged to a mutual fund as a percentage of a fund's average net assets. The expense ratio excludes: performance fees, interest arising from loans to funds, brokerage and transaction costs, foreign exchange earnings or losses, tax deducted at the source, front end loads, and dividend and other distributions to unit holders (Singapore Business Times, 11th July, 2001.

23 Business Times, Singapore, 7th July, 2001

24 Business Times, Singapore (2001) 22nd June, 27th June, 11th July and 18th July.

25 Hong Kong's public assistance to the elderly provides basic pension for the aged poor, disabled elder and those above 70 years of age. An aged, able-bodied, single individual, with no assets would receive US $\$ 328$ per month. An aged married couple, with assets of less than US $\$ 32,564$ and a monthly income of less than US $\$ 1,250$ would receive US $\$ 80$ each per month. Singapore is tentatively taking small steps (such as depositing small amounts to CPF accounts of all citizens from the budget and depositing small amounts in the Medisave accounts of selected elderly from the budget) to de-link CPF accumulations from wage contributions. But these are too insignificant to date to satisfy the requirements of the tax-financed pillar.

\section{Bibliography}

Asher, M. (2000) 'Reforming Civil Service Pensions in Selected Asian Countries', Prepared for the World Bank Social Security Workshop. Washington, D.C. March 2000.

Asher, M. (1998) 'The Future of Retirement Protection in Southeast Asia', International Social Security Review 51:1(3-30).

DiBiasio, J. (2001c) 'The Introvert', Pensions Asia, Hong Kong, A FinanceAsia Publication, March.

Fox, L. and Palmer, E. (2001) 'New Approaches to Multipillar Pension Systems: What in the World is Going On?' in R. Holzmann and J. E. Stiglitz (eds), New Ideas About Old Age Security, The World Bank, Washington, DC, 90-132.

International Securities Institute, (1998) A Capital Guide to Marketing Unit Trusts and Mutual Funds in Asia, International Securities Institute, Hong Kong.

Organization for Economic Cooperation and Development (OECD), (2001) OECD Private Pensions Conference 2000, Private Pensions Series, No. 3 (Paris: OECD).

Organization for Economic Cooperation and Development (OECD), (2001) Private Pension Systems: Administrative Costs and Reforms, Private Pensions Series, No. 2 (Paris: OECD).

Organization for Economic Cooperation and Development (OECD), (2000) Private Pension Systems and Policy Issues, Private Pensions Series, No. 1 (Paris: OECD).

Standard and Poor's 2000 Emerging Stock Markets Factbook 2000, Standard and Poor's, New York.

Vittas, D. (1998) 'Regulatory Controversies of Private Pension Funds', Development Research Group, The World Bank, Mimeo. 